
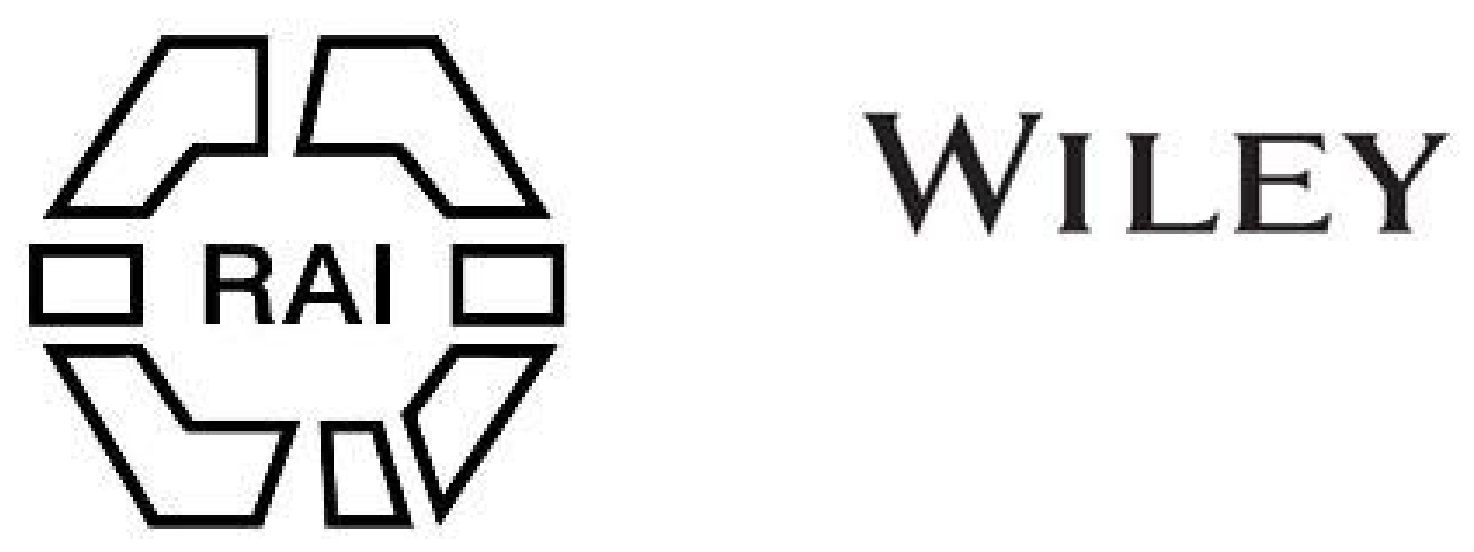

24. An Early Palaeolithic Flint Implement from West Runton, Norfolk.

Author(s): J. Reid Moir

Source: Man, Vol. 22 (Mar., 1922), pp. 34-36

Published by: Royal Anthropological Institute of Great Britain and Ireland

Stable URL: http://www.jstor.org/stable/2839640

Accessed: 26-06-2016 17:05 UTC

Your use of the JSTOR archive indicates your acceptance of the Terms \& Conditions of Use, available at

http://about.jstor.org/terms

JSTOR is a not-for-profit service that helps scholars, researchers, and students discover, use, and build upon a wide range of content in a trusted digital archive. We use information technology and tools to increase productivity and facilitate new forms of scholarship. For more information about JSTOR, please contact support@jstor.org.

Royal Anthropological Institute of Great Britain and Ireland, Wiley are collaborating with JSTOR to digitize, preserve and extend access to Man 
An Early Palæolithic Flint Implement from West Runton, Norfolk. By J. Reid Moir.

In the year $1878 \mathrm{Mr}$. A. C. Savin, the well-known palæontologist of Cromer, found, embedded at a depth of about 12 feet from the surface of the ground, in a gravel bed exposed in the cliff at West Runton, Norfolk, the palæolithic flint implement described in this note. This specimen is referred to in Evans's " Ancient Stone Implements of Great Britain," second edition, p. 572, as follows :- "Many miles " to the east, but still in Norfolk, there is seen in the cliff at West Runton, near " Cromer, what appears to be the channel of an old river, filled up with gravelly " deposits. In these, at a depth of 12 feet from the surface . . . Mr. A. C. "Savin, of Cromer, in 1878, found in situ a fine, well-wrought ovate implement of " flint $4 \frac{3}{4}$ inches long." Again, in "The Fenland Past and Present" (1878), p. 536, Mr. S. B. J. Skertchly, in giving a list of the various places in England where, up to the time at which he was writing, palæolithic flint implements had been found, quotes a number of localities, and adds " as well as quite recently at West Runton in " Norfolk." It may be noted here that Mr. Skertchly was of opinion that the English gravel beds containing palæolithic implements are of inter-glacial age. Finally, in "The Geology of the Country around Cromer" (Memoirs of the Geological Survey, explanation of Sheet $68 \mathrm{E}$ ), p. 120 , is to be found the following note, written by the late Mr. Clement Reid :- "No Post-glacial deposits occur between

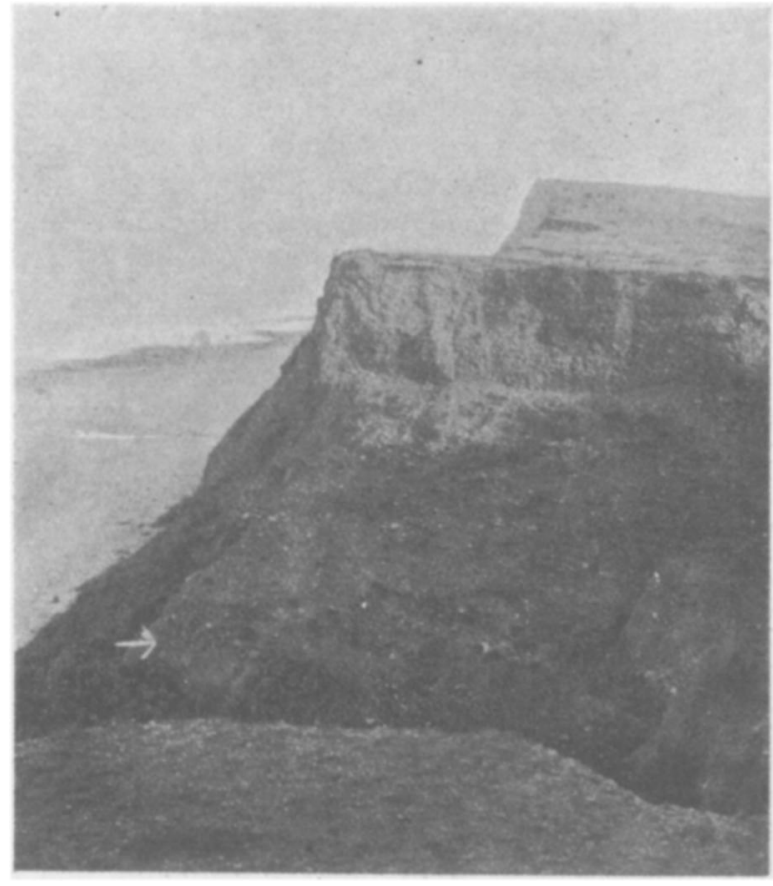

Fig. 1.-VIEW OF SECtion OF GRAVEx at WEST RUNTON, LOOKING SOUTH-EAST. THE BASE OF THE GRAVEL IS INDICATED BY ARROW ON LEFT.

"Mundesley and Runton, but "at West Runton Valley " gravels again cap the cliff. " Though no fossils have been

" found, this section is of " special importance as being " the most northerly locality " where, up to the present " time, palæolithic implements " have been found in stratified " beds. In 1878 Mr. Alfred "Savin, of Cromer, obtained " at this place an axe of the " ordinary type-the only " one, as far as I am aware, " yet found on the Norfolk " coast." In the folding plate, at the back of the Survey Memoir mentioned, appears a section of the cliff at West Runton, and $\mathrm{Mr}$. Reid shows a depression filled with gravel, in which the implement was found. This deposit he classes as "valley gravel." Immediately to the north-westward of this implementiferous deposit is shown another and deeper hollow, also filled with gravel, and this accumulation Mr. Reid regarded as of glacial origin. It will thus be seen that, while Sir John Evans and Mr. Clement Reid looked upon the implementiferous gravel bed at 
West Runton as being apparently of post-glacial date, Mr. Skertchly, on the other hand, regarded it as being of inter-glacial age.

In a paper published recently (Proc. Prehist. Soc. East Anglia, Vol. III., part 11, pp. 219-243) I mentioned Mr. Savin's specimen from West Runton, and, through the finder's kindness, I am now able to figure and describe it. So far as I am aware, this had not been done before, though, in view of the importance of the implement, this is to be regretted. The exposure of gravel where Mr. Savin made his discovery occurs in the cliff a few hundred yards south-eastward of West Runton Gap. I know the site intimately, having visited it frequently during the past eighteen months : the gravel comes in immediately under the thin capping of surface soil, and is about 15 feet in thickness. It rests upon the Contorted Drift, and, so far as my observations have gone, is unstratified. Many stones in the deposit can be seen standing on end, and this peculiarity, together with the "tumbled" appearance of the bed, would seem to point to its glacial origin. A number of erratics-chiefly quartzites-and much battered flint pebbles of a greyish colour (such as occur in

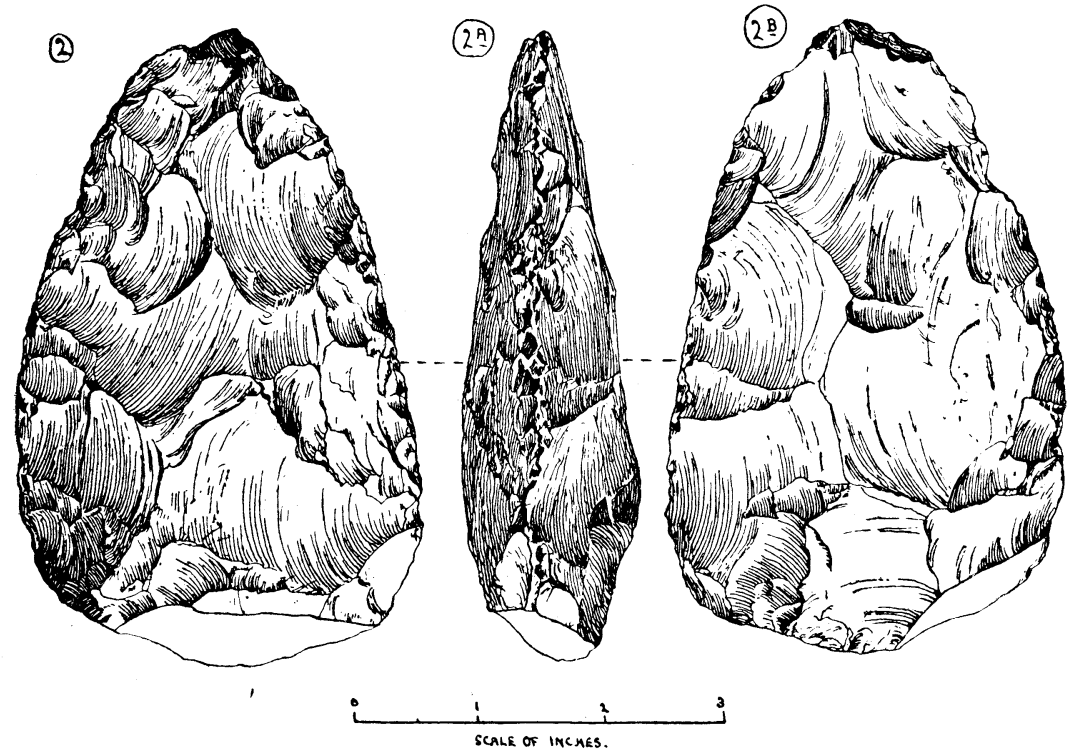

FIGS. 2, 2A, AND 2B.-THREE VIEWS OF PALÆOLITHIC FLINT IMPLEMENT FOUND BY MR. SAVIN IN 1878, IN GRAVEL AT WEST RUNTON.

profusion in beds of undoubted glacial gravel in the adjacent cliffs) are to be observed in the deposit, and, towards its base, there is to be seen a sandy, loamy, and perhaps impersistent seam, averaging about 1 foot in depth. The accompanying photograph (Fig. 1) of the part of the West Runton gravel from which Mr. Savin recovered his implement, shows the surface of the gravel beneath the humus, and the base (indicated by an arrow on the lower left-hand side of the illustration) resting upon the underlying Contorted Drift. The deposits of gravel which, in places, cap the cliffs of the Norfolk coast, occur mostly, though not exclusively, in hollows in the underlying beds. And I see little reason to doubt but that this accumulation at West Runton is part and parcel of the widespread glacial gravel of the Cromer district. This deposit is, probably, of the same age as the "Middle" Glacial gravel of Suffolk (Wood and Harmer, Quart. Journ. Geol. Soc., Vol. VII., pp. 19-31). I have failed to detect any fundamental difference in appearance and composition between the West Runton gravel and the undoubted glacial gravels exposed in the cliffs of the Norfolk coast, and I have failed also to notice any difference or line of 
demarkation between the implementiferous gravel at West Runton and the deposit immediately adjacent to it, which was mapped by Mr. Clement Reid as of glacial age.

The implement found in the West Runton bed is illustrated in Figs. 2, 2A, and $2 \mathrm{~B}$, and I have to thank Mr. E. T. Lingwood for being so good as to draw it for me. The specimen is almost unabraded, and exhibits neither incipient cones of percussion, nor striæ upon its surfaces. It is of a brownish-coffee colour, darker in places than in others, and has been fashioned by blows removing somewhat large and broad flakes. The larger edges of the specimen are more or less straight, and it seems possible it may be referred to the later portion of Chellean-palæolithic-times. I conclude, then, with Skertchly, that in this implement, and its provenance, we are provided with still further evidence in favour of the view that the earlier palæolithic flint implements must be relegated, in this country, as for many years they have been upon the Continent of Europe, to glacial times.

Mr. Guy Maynard has taken from the West Runton gravel a small ovate palæolithic implement, while Mr. J. E. Sainty and myself have found various flakes of human manufacture in the same deposit. All the specimens are in my possession, and I hope to publish an account of them in the near future.

J. REID MOIR.

\section{India: Sociology.}

Chattopadhyay.

\section{Levirate and Kinship in India. By K. P. Chattopadhyay.}

According to Rivers's theory of kinship and social organisation, "the 25

" terminology of relationship" is " rigorously determined by social conditions; and

" if this position" be "established and accepted, systems of relationship furnish

" us with a most valuable instrument in studying the history of social institutions."*

An interesting example of this kind is found in the system of relationship in Northern India. The mode of denoting relationship is classificatory; and the necessity of special terms for each of the relations-mother's brother, mother's sister, father's brother, father's sister (and their wives and husbands by corresponding terms) is obvious when we remember that marriage within the caste itself (endogamy) is hedged round by bars of sapinda (relations of seventh degree) and sagotra (bearing the same patronymic title; these can never intermarry-a custom resembling clan exogamy).

But there is one special term which does not lend itself to any such explanation. It is the distinction between the elder and younger brothers of the husband. No distinction is made in terminology between the husband's elder and younger sisters or between the wife's elder and younger brothers or sisters. In fact the distinction is unique in the classificatory system of relationship in Northern India (Hindus). If it be urged that the elder brother is distinguished in some places (as, for example, Bengal) by a special term $d \bar{a} d \bar{a}$, it should be remembered that the elder sister is also distinguished by a similar term didi, and there is no resultant corresponding distinction between the elder and younger sisters of the husband. Further, any such distinction is completely absent in the terminology of the wife's brothers and sisters. And, finally, there is no distinction of elder and younger brother, by a special term for the elder, in Gujarat and United Provinces, while the distinction between the husband's elder and younger brother is present.

I subjoin a table of terms of certain relationships to illustrate the peculiarity. It shows that we have to look for the origin of the distinction in some special privilege possessed by the younger brother with respect to the elder brother's wife. The system of transliteration adopted is that used in Macdonnell and Keith's

* "Kinship and Social Organisation" (1914), page 1. 